\title{
Bovine Pituitary Extract
}

National Cancer Institute

\section{Source}

National Cancer Institute. Bovine Pituitary Extract. NCI Thesaurus. Code C29784.

A substance isolated from the pituitary glands of cattle which contains a variety of proteins, hormones, and growth factors. Bovine pituitary extract is used in research as a mitogenic supplement in the cell culture of various epithelial and endothelial cell lines.

$(\mathrm{NCl04})$ 